\title{
MedChemComm
}

REVIEW

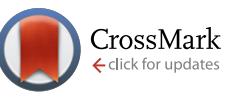

Cite this: Med. Chem. Commun., 2015, 6, 2054

\section{Thermoresponsive fluorinated small-molecule drugs: a new concept for efficient localized chemotherapy}

\author{
Catherine M. Clavel, Patrycja Nowak-Sliwinska, Emilia Păunescu and Paul J. Dyson*
}

Hyperthermia is currently being explored as an adjuvant treatment to conventional therapies with chemotherapeutic agents based on thermoresponsive macromolecules. Although the concept of hyperthermia has existed for many years it has yet to become routinely used in the clinical management of cancer. The development of small thermoresponsive molecules could help to change this paradigm. Temperaturesensitive compounds have recently been developed by covalently modifying drug and drug-like molecules with thermomorphic perfluorinated appendages. Lead thermoresponsive compounds have been validated in a pre-clinical model, displaying high tumor growth inhibition, with strong synergies observed between hyperthermia and the thermomorphic compounds.

Received 15th September 2015 Accepted 2nd October 2015

DOI: $10.1039 / \mathrm{c} 5 \mathrm{md} 00409 \mathrm{~h}$

www.rsc.org/medchemcomm referred to as thermal ablation). ${ }^{9}$ Importantly, cancer tissue is more thermosensitive than normal tissue between $42{ }^{\circ} \mathrm{C}$ and $45{ }^{\circ} \mathrm{C},{ }^{10}$ with a proportional relationship between cell death and the exposure time/temperature. ${ }^{11}$ There are various mechanisms by which local hyperthermia affects a cell leading to an enhanced antitumor response, see Fig. $1 .{ }^{12}$ Hyperthermia disrupts cell membrane function, enhances permeability and modifies the fluidity, stability and shape of the membrane, impeding transmembrane transport proteins and cell surface receptors. ${ }^{13,14}$ Heat transfer away from tumor tissue depends on the rate and volume of tumor perfusion, ${ }^{15}$ and this process is usually less efficient in malignant tissue compared to healthy tissues, ${ }^{16,17}$ enhancing the selectivity of hyperthermia. ${ }^{18}$

Hyperthermia can effect cells in many different ways. ${ }^{19}$ It is known that heat can alter the structure of endogenous molecules such as lipids, nucleotides and proteins. Although the effects on lipids are reversible, the effects on DNA, i.e. the generation of double strand breaks, can be substantial and less easily reversed. However, the largest effects of hyperthermia are believed to be on proteins as they undergo denaturation and aggregation at temperatures $>39^{\circ} \mathrm{C}$. This leads to inhibition of many cellular processes such as cell cycle arrest, inactivation of protein synthesis and inhibition of DNA synthesis and repair, resulting in inhibition of proliferation and cell death. ${ }^{20-22}$ Other important cellular changes induced by hyperthermia include the destruction of the cytoskeleton, making cellular motility difficult, and enhanced degradation of proteins through the proteasome and lysosomal pathways. In addition, changes in cellular metabolism resulting in decreased availability of ATP and enhanced production of reactive oxygen species (ROS) have been 


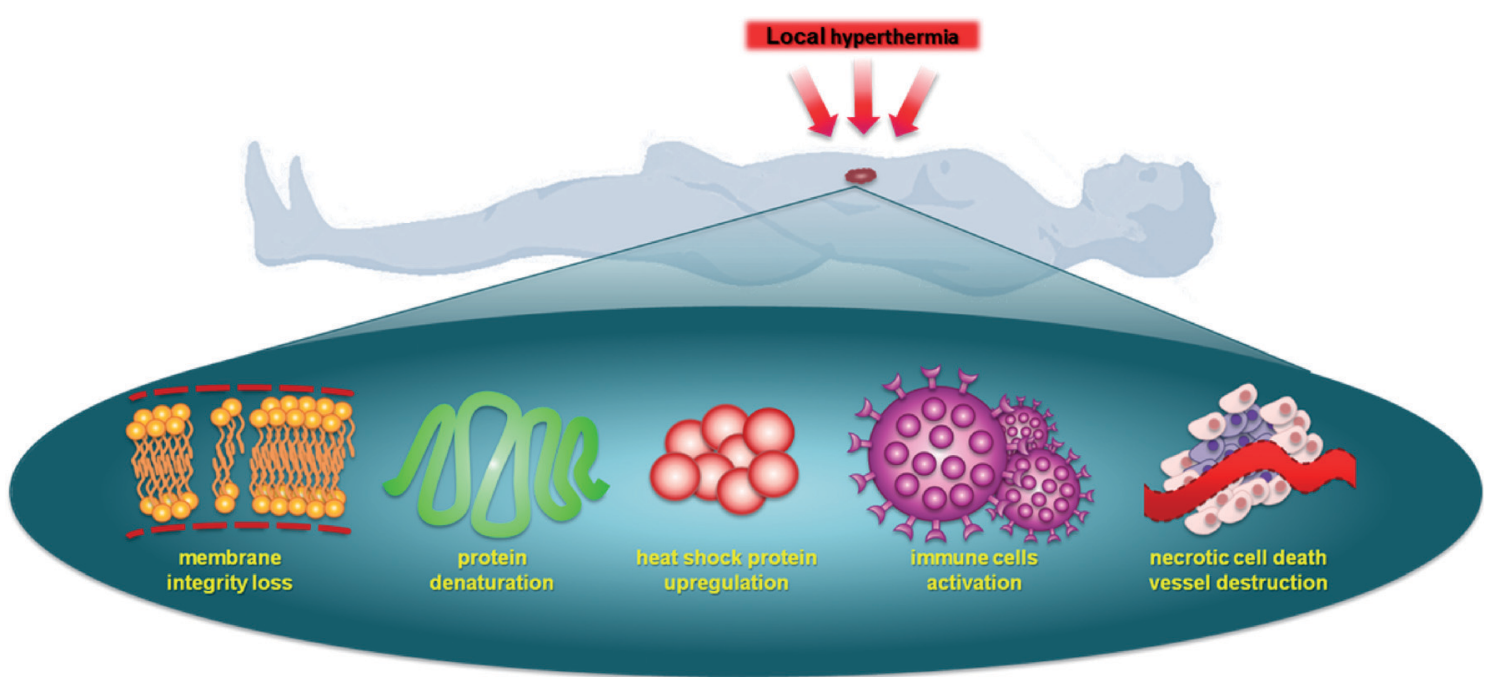

Fig. 1 Different mechanisms of antitumor activity induced by local hyperthermia of tumors: loss of membrane integrity, upregulation of heat shock proteins, activation of immune cells, necrotic cell death and vessel destruction.

described. $^{23,24}$ All these cellular changes ultimately lead to the loss of cell membrane integrity.

While these changes occur at the cellular level in all cells in the heated area, at a higher level vascular disruption also takes place, leading to vascular dysfunction and tissue eradication. ${ }^{25,26}$ However, as the vasculature is perfused the extent of hyperthermia is more moderate in the vessels, but nevertheless may result in better tumor perfusion. Such increased perfusion facilitates increased trafficking of immune cells including $T$ cells and dendritic cells. ${ }^{27,28}$ The abovementioned mechanisms may be differently balanced in specific tumor types as well as from patient to patient. Since heating tumors activates an immune response, at least in part by the upregulation of heat shock proteins, and since activity of some chemotherapeutics depend on heat shock proteins, ${ }^{29}$ it may suggest that these treatment strategies may act synergistically.

\section{Combining small-molecule anticancer drugs with hyperthermia}

Combining hyperthermia with chemotherapy frequently gives contrasting results in vitro and in vivo due to the ways in which hyperthermia effects the tumor microenvironment (see above). Drug exposure to cells remains relatively stable in vitro whereas in malignant tissue it is affected by the changes of the tumor blood flow induced by hyperthermia. ${ }^{30}$
Nevertheless, early studies demonstrated that alkylating agents such as methyl methanesulfonate (Fig. 2) exhibit superior effects in conjunction with hyperthermia at 41-42 ${ }^{\circ} \mathrm{C},{ }^{31,32}$ attributed to higher levels of DNA single strand breaks and reduced DNA repair. ${ }^{33}$ In other studies comparing melphalan, cisplatin and cyclophosphamide in combination with hyperthermia $\left(41^{\circ} \mathrm{C}\right)$ only cyclophosphamide resulted in an improved therapeutic response. ${ }^{34,35}$

Cisplatin was found to reduce tumor growth more efficiently in mouse mammary and rat glioma tumors when applied simultaneously with hyperthermia, ${ }^{36}$ although renal damage in rats resulting from the combination treatment were heightened. ${ }^{37}$ No enhancements in the reduction of tumor growth were detected for the antimetabolites, vinblastine and etoposide (Fig. 3) when combined with

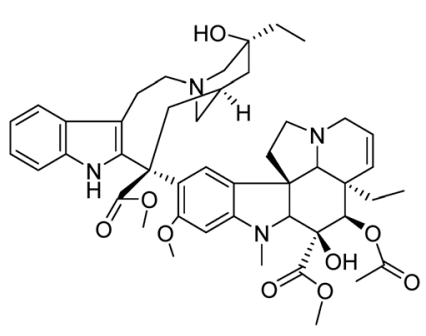

(a)

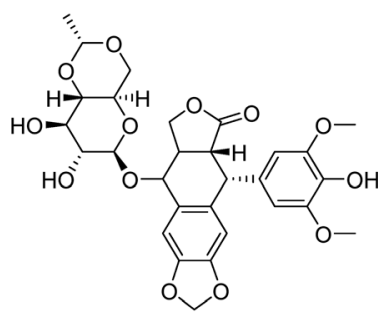

(b)
Fig. 3 Structures of the antimetabolites vinblastine (a) and etoposide (b).<smiles>COS(C)(=O)=O</smiles>

(a)

(b)<smiles>O=P1(N(CCCl)CCCl)NCCCO1</smiles>

(c)<smiles>N[Pb](N)(Cl)Cl</smiles>

(d)<smiles>N[P]1(N)OC(=O)C2(CCC2)C(=O)O1</smiles>

(e)

Fig. 2 Structures of the alkylating agents methyl methanesulfonate (a), melphalan (b), cyclophosphamide (c), cisplatin (d) and carboplatin (e). 
hyperthermia, possibly due to drug instability at the elevated temperatures. $^{38}$

To improve treatment protocols and reduce the side effects of hyperthermia, heating can be applied regionally or only locally and, furthermore, by careful timing of the treatment, with respect to drug administration, additional enhancements are possible. Indeed, the sequence and timing of chemotherapy and hyperthermia are critical for enhanced tumor reduction and it was shown for several drugs (cisplatin, melphalan and carboplatin, Fig. 2) that simultaneous administration of drug and heat is optimal. ${ }^{39,40}$ As mentioned above, hyperthermia can modify the tolerance of a tumor to chemotherapy leading to thermotolerance, an adaptive survival response, induced by heat preconditioning, whereby cells become resistant to a subsequent lethal insult. Therefore, the most advantageous treatment schedules involve administration of a chemotherapeutic before application of hyperthermia, ${ }^{41}$ or the simultaneous application of the two regimens. ${ }^{39,40}$ For cisplatin, it was shown that the concentration of the drug in the tumor is higher when injected prior to hyperthermia, presumably because hyperthermia induces vasodilatation following administration leading to an initial enhancement of drug retention in the tumor microenvironment with subsequent stabilization of tumor blood flow enhancing entrapment of the drug. ${ }^{42}$

Continuously circulating a heated solution containing chemotherapeutic agents inside the peritoneal cavity, a technique known as hyperthermic intraperitoneal chemotherapy, allows fast drug delivery to the gastric region. This approach was subsequently applied in clinical trials with cytoreductive surgery in gastric and ovarian carcinomas, in combination with cisplatin (Fig. 2) or mitomycin $\mathrm{C}$ (Fig. 4), in the treatment of malignant mesothelioma in combination with mitomycin C in phase II clinical trials, ${ }^{43-45}$ and in a phase III study on colorectal carcinoma employing 5-fluorouracil and leucovorin (Fig. 4). ${ }^{46-48}$
Promising results were obtained with gemcitabine (Fig. 4) combined with cisplatin and regional hyperthermia as a second-line treatment for gemcitabine-resistant advanced and metastatic tumors. ${ }^{49}$ Moreover, patients with cervical cancer that did not respond to radiotherapy were administered weekly with cisplatin and regional hyperthermia in a phase II study with a response rate of $50 \%$ observed for hyperthermia-chemotherapy treated patients compared to only $15 \%$ for patients treated with chemotherapy alone. ${ }^{50,51}$

In phase II clinical studies doxorubicin, ifosfamide and etoposide $^{52}$ or etoposide and ifosfamide (Fig. 5) ${ }^{53}$ were applied together with regional hyperthermia and shown to improve local control in high-risk, soft-tissue sarcoma compared to chemotherapy alone (a four year overall survival of $59 \%$ was achieved with the latter combination compared to $40 \%$ for chemotherapy alone). These promising results led to large and randomized phase III clinical trials with the first completed study showing moderate toxicity including skin burns, but with the response rate more than doubling under hyperthermia (28.8 vs. 12.7\%), and an increased local progression-free survival at 2 years $(76 \%$ vs. $61 \%){ }^{7}$ Another study investigated the chemotherapy combination comprising ifosfamide, carboplatin and etoposide as a second-line treatment with hyperthermia in soft-tissue sarcoma refractory with an objective response rate of $20 \% .{ }^{54}$ In phase III clinical trials hyperthermia led to significant clinical benefits using regional hyperthermia for superficial and deep local advanced tumors such as high-risk soft-tissue sarcoma.

\section{Macromolecular thermoresponsive systems}

The application of small molecules applied with hyperthermia indicates the considerable potential of the approach in cancer therapy. However, the molecules described above were

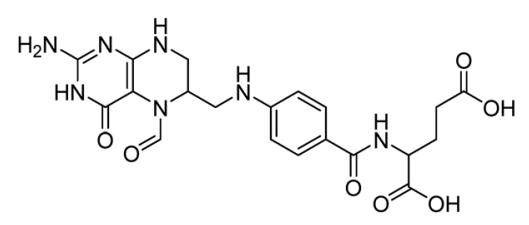

(a)

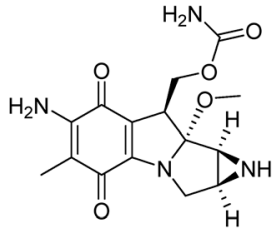

(b)

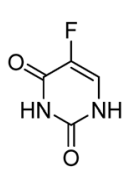

(c)

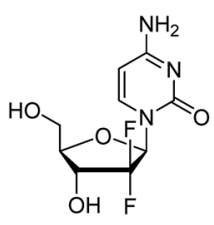

(d)

Fig. 4 Structures of leucovorin (a) mitomycin C (b), 5-fluorouracil (c) and gemcitabine (d).<smiles>COc1cccc2c1C(=O)c1c(O)c3c(c(O)c1C2=O)C[C@@](O)(C(=O)CO)C[C@@H]3O[C@H]1C[C@H](N)[C@H](O)[C@H](C)O1</smiles>

(a)<smiles>O=P1(NCCCl)OCCCN1CCCl</smiles>

(b)<smiles>Cn1nnc2c(C(N)=O)ncn2c1=O</smiles>

(c)

Fig. 5 Structures of doxorubicin (a), ifosfamide (b) and temozolomide (c). 
not originally designed to be applied with hyperthermia, indicating that more effective compounds could be developed. Initial attempts to adapt compounds to hyperthermia were based on the encapsulation of established drugs in liposomes with temperature-dependent drug release characteristics. These macromolecular systems have the added advantage that liposomes also preferentially accumulate in solid tumors due to the enhanced permeation and retention of macromolecules. ${ }^{55}$

Notably, liposomal formulations of doxorubicin (Fig. 5) have been extensively studied in thermotherapy. ${ }^{56,57} \mathrm{~A}$ drug delivery system that shows considerable promise is based on a low temperature sensitive liposome containing doxorubicin, termed ThermoDox®, which releases the drug in a few seconds at $42{ }^{\circ} \mathrm{C} .{ }^{58,59}$ The heat-sensitive liposome changes structure as a function of temperature and, as the temperature increases, pores in the liposome are created which release doxorubicin directly into the heated tumor. ${ }^{60}$ ThermoDox® is currently in phase III clinical trials in combination with hyperthermia for the treatment of hepatocellular carcinoma. However, a significant proportion of the encapsulated doxorubicin in ThermoDox® is lost following intravenous administration ${ }^{61,62}$ and, consequently, alternative drug delivery systems have been developed. A cationic thermoresponsive liposomal system incorporating doxorubicin and ammonium bicarbonate operates via an alternative mechanism. At the heated tumor site $\mathrm{CO}_{2}$ bubbles are produced that induce the release of the doxorubicin. ${ }^{57}$ In another variant the doxorubicin is coordinated to manganese ions, which enhances encapsulation without impacting on the temperaturetriggered release and pharmacokinetics of the drug delivery system. ${ }^{61}$ Cisplatin encapsulated in preformed thermoresponsive cholesterol-containing liposomes is stable at 37 ${ }^{\circ} \mathrm{C} \quad(<5 \%$ released), whereas $>95 \%$ is released within 5 minutes at $42{ }^{\circ} \mathrm{C} .{ }^{63}$ Nanoparticles have also been explored as thermoresponsive drug nanocarriers, including iron oxide magnetic nanoparticles, ${ }^{64}$ acid-capped poly(lactic-co-glycolic acid) nanoparticles, ${ }^{65}$ silica-coated magnetic lanthanumstrontium manganite nanoparticles ${ }^{66}$ or other surfacemodified nanoparticles, ${ }^{67,68}$ all incorporating doxorubicin as the active drug molecule.

An advantage of certain macromolecular drug delivery systems is that they can traverse the blood-brain barrier. ${ }^{69}$ For example, a liposomal doxorubicin formulation (Caelyx®) able to cross the blood-brain barrier was found to accumulate in glioblastoma and brain metastases. ${ }^{70}$ A multimodality treatment comprising radiotherapy, hyperthermia and chemotherapy, i.e. temozolomide (Fig. 5), with added Caelyx ${ }^{\circledR}$ for resistant cases, led to enhanced survival rates in a glioblastoma clinical trial. ${ }^{71}$ More than $50 \%$ patients remained alive after 26 months whereas the median survival following surgery is usually $<4$ months, which is only slightly improved with radiotherapy. ${ }^{72,73}$

Heat seeking drug-loaded polypeptide nanoparticles based on a thermally responsive elastin-like polypeptide conjugated to multiple copies of doxorubicin have been reported recently. ${ }^{74}$ These nanoparticles were able to target tumors that were externally heated to $42{ }^{\circ} \mathrm{C}^{75}$ Thermal cycling (heating and cooling) of the tumors following injection of the thermally responsive nanoparticles results in a significant enhancement of doxorubicin accumulation in the tumor. ${ }^{74,76}$

\section{New small-molecule thermoresponsive compounds}

Despite the development of macromolecular drug formulations for thermotherapy, notably liposomal formulations, small-molecule drugs not designed for use in combination with hyperthermia continue to be evaluated in clinical trials. There are clinical advantages in using low molecular weight thermosensitive drugs that are selectively activated at the tumor site by the application of hyperthermia. In this context many highly fluorinated compounds have excellent thermomorphic properties ${ }^{77-79}$ and fluorine compounds already play an important role in medicinal chemistry. ${ }^{80-82}$ Numerous anticancer drugs such as 5-fluorouracil (Fig. 4), ${ }^{83}$ rosuvastatin and fluticasone ${ }^{84}$ and torcetapib ${ }^{85}$ contain one or more fluorine atoms (Fig. 6). Perfluorinated systems have also been investigated as drug delivery systems and were shown to exhibit prolonged circulation times in the blood. ${ }^{86}$ Drug absorption and biodistribution rely mainly on the lipophilicity/hydrophilicity of the system and fluorine-containing compounds have unique properties in this regard, with diverging lipophilic and hydrophobic characteristics depending on the fluorine atom content.

Perfluorinated solvents undergo temperature-dependent miscibility with organic solvents and water ${ }^{87,88}$ and the solubility of certain fluorinated compounds varies considerably as a function of temperature. ${ }^{89,90}$ Moreover, certain fluoropolymers exhibit biocompatible characteristics and have been

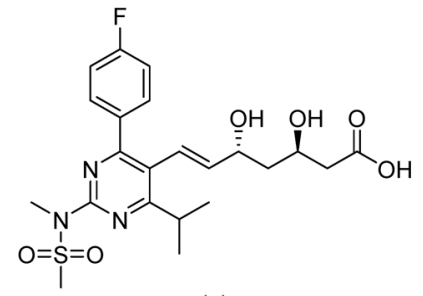

(a)

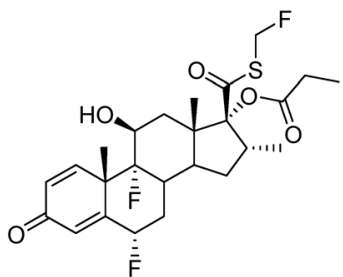

(b)

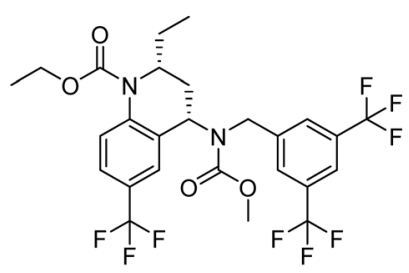

(c)

Fig. 6 Structures of the fluorine-containing drugs rosuvastatin (a), fluticasone (b) and torcetrapib (c). 
evaluated in various biomedical applications. ${ }^{91,92}$ Based on these observations, the first small-molecule anticancer compounds containing perfluorinated chains attached via a phosphine ligand to bioactive ruthenium(II)-arene moieties were designed and evaluated in vitro (Fig. 7, PTA = 1,3,5-triaza-7phosphatricyclo[3.3.1.1]decane). ${ }^{93}$ The solubility of the compounds at $37^{\circ} \mathrm{C}$ was low and in some cases increased considerably at $42{ }^{\circ} \mathrm{C}$. Some of the compounds were found to be strongly cytotoxic to human ovarian A2780 and A2780cisR cancer cell lines (the latter having acquired resistance to cisplatin) under normal conditions, i.e. at $37^{\circ} \mathrm{C}$. Including a 42 ${ }^{\circ} \mathrm{C}$ heating cycle for 2 hours during the incubation period increased their cytotoxicity.

Although non-fluorinated ruthenium(II)-arene compounds related to those shown in Fig. 7 show encouraging in vivo properties, ${ }^{94-100}$ as yet, none have progressed to clinical trials. Consequently, the widely explored and clinically approved alkylating agent, chlorambucil, $p-\left(\mathrm{Cl}\left(\mathrm{CH}_{2}\right)_{2}\right)_{2} \mathrm{~N}-$ $\mathrm{C}_{6} \mathrm{H}_{4}-\left(\mathrm{CH}_{2}\right)_{3}-\mathrm{CO}_{2} \mathrm{H}$, was derivatized with perfluorinated chains via an ester linkage in order to better assess the thermoresponsive potential of the compound. These chlorambucil derivatives were shown to exhibit significant differences when applied to cancer cells under normal conditions and under mild hyperthermia at $42{ }^{\circ} \mathrm{C} .{ }^{101}$ Notably, chlorambucil modified with a long $\left(\mathrm{C}_{10}\right)$ perfluorous chain, i.e. $p$ - $\left(\mathrm{Cl}\left(\mathrm{CH}_{2}\right)_{2}\right)_{2} \mathrm{~N}-\mathrm{C}_{6} \mathrm{H}_{4}-\left(\mathrm{CH}_{2}\right)_{3}-\mathrm{CO}_{2}-\left(\mathrm{CH}_{2}\right)_{2}\left(\mathrm{CF}_{2}\right)_{9} \mathrm{CF}_{3}$ (Fig. 8), is only cytotoxic following a 2 hour hyperthermia signal. In the various cancer cell lines tested the compound is consistently more cytotoxic following hyperthermia. For example, at $37^{\circ} \mathrm{C}$ in the A2780 and A2780cisR cell lines the compound is inactive at the maximum concentration that could be tested $(200 \mu \mathrm{M})$, whereas with the inclusion of a 2 hour period at 42 ${ }^{\circ} \mathrm{C}$ during the 72 hour incubation period $\mathrm{IC}_{50}$ values of 37 and $40 \mu \mathrm{M}$, respectively, were obtained. In the same cell lines chlorambucil was less cytotoxic when applied in combination with hyperthermia, and analogues in which the fluorous chain is replaced by a hydrocarbon chain do not show clear thermoresponsive behavior. Note that the $\log P$ values of the chlorambucil derivatives with fluorous chains are significantly higher (ca. 9-12) than those with alkyl chains (ca. 6). In the case of the longest chain derivatives (both fluorous and alkyl chains) a significant increase in solubility in water was observed as the temperature changes from 37 to $43^{\circ} \mathrm{C}^{101}$<smiles>O=C(O)CCCc1ccc(N(CCCl)CCCl)cc1</smiles><smiles>O=C(CCCc1ccc(N(CCCl)CCCl)cc1)OCCC(F)(F)C(F)(F)C(F)(F)C(F)(F)C(F)(F)C(F)(F)C(F)(F)C(F)(F)C(F)(F)C(F)(F)F</smiles>

(b)

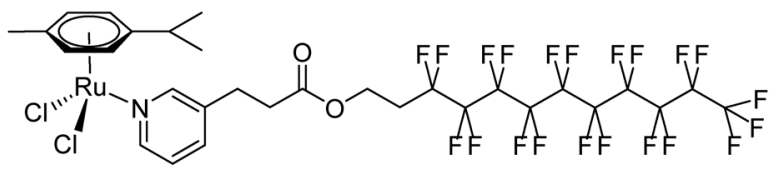

(c)

Fig. 8 Structures of chlorambucil (a), p- $\left(\mathrm{Cl}\left(\mathrm{CH}_{2}\right)_{2}\right)_{2} \mathrm{~N}-\mathrm{C}_{6} \mathrm{H}_{4}-\left(\mathrm{CH}_{2}\right)_{3}-$ $\mathrm{CO}_{2}-\left(\mathrm{CH}_{2}\right)_{2}\left(\mathrm{CF}_{2}\right)_{9} \mathrm{CF}_{3}$ (b) and $\left[\mathrm{Ru}\left(\eta^{6}-p\right.\right.$-cymene $) \mathrm{Cl}_{2}\left(\mathrm{C}_{5} \mathrm{H}_{4} \mathrm{~N}-3-\left(\mathrm{CH}_{2}\right)_{2}-\right.$ $\left.\left.\mathrm{CO}_{2}-\left(\mathrm{CH}_{2}\right)_{2}\left(\mathrm{CF}_{2}\right)_{9} \mathrm{CF}_{3}\right)\right]$ (c).

The thermoresponsive properties of $p-\left(\mathrm{Cl}\left(\mathrm{CH}_{2}\right)_{2}\right)_{2} \mathrm{~N}$ $\mathrm{C}_{6} \mathrm{H}_{4}-\left(\mathrm{CH}_{2}\right)_{3}-\mathrm{CO}_{2}-\left(\mathrm{CH}_{2}\right)_{2}\left(\mathrm{CF}_{2}\right)_{9} \mathrm{CF}_{3}$ was also demonstrated in vivo using a mouse model bearing the human LS-174 $\mathrm{T}$ tumor. ${ }^{102}$ At a dose of $12.5 \mathrm{mg} \mathrm{kg}{ }^{-1}$, administered a total of three times every four days, a reduction in tumor growth of $59 \%$ is observed under normal conditions, i.e. without hyperthermia. When combined with a 30 minute hyperthermia signal a few minutes after injection tumor growth inhibition increases to $79 \%$.

The mechanism of tumor cell death induced by the compound appears to be the same as that of chlorambucil itself and involves DNA damage. However, the mechanism of thermal activation remains unclear, although it would appear to involve increased solubility at the heated tumor site with concomitant cleavage of the fluorous chain at the ester linker. Compounds in which the fluorous chain is covalently linked to the drug via non-cleavable groups do not appear to be endowed with such extensive thermoresponsive activity. Hence, the original thermoresponsive ruthenium complexes mentioned above were redesigned with the fluorous chain tethered to a pyridine ligand via an ester linkage (Fig. 8). ${ }^{103}$ These ruthenium

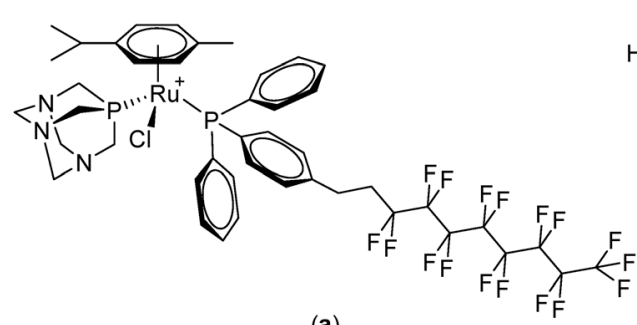

(a)

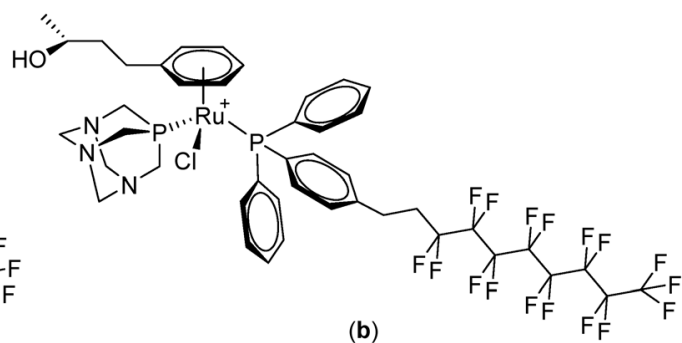

Fig. 7 Ruthenium(॥)-arene complexes with fluorinated phosphines that modest exhibit thermoresponsive behavior; [Ru( $\eta^{6}-p$ cymene)(PTA)Cl(PPh $\left.\left.\left(p-\mathrm{C}_{6} \mathrm{H}_{4}\left(\mathrm{CH}_{2}\right)_{2}\left(\mathrm{CF}_{2}\right)_{7} \mathrm{CF}_{3}\right)\right]\right]\left[\mathrm{BF}_{4}\right]$ (a) and $\left[\mathrm{Ru}\left(\eta^{6}\right.\right.$-p-phenyl-2-butanol)(PTA)Cl($\left.\left(\mathrm{PPh}_{2}\left(p-\mathrm{C}_{6} \mathrm{H}_{4}\left(\mathrm{CH}_{2}\right)_{2}\left(\mathrm{CF}_{2}\right)_{7} \mathrm{CF}_{3}\right)\right)\right]\left[\mathrm{BF}_{4}\right](\mathrm{b})$. The counter anion is not shown. 
compounds display a remarkable selectivity to cancer cells in vitro when used in combination with a 2 hour hyperthermia treatment of $41{ }^{\circ} \mathrm{C}$. For the most effective compound, $\left[\mathrm{Ru}\left(\eta^{6}\right.\right.$-p -cymene $\left.) \mathrm{Cl}_{2}\left(\mathrm{C}_{5} \mathrm{H}_{4} \mathrm{~N}-3-\left(\mathrm{CH}_{2}\right)_{2}-\mathrm{CO}_{2}-\left(\mathrm{CH}_{2}\right)_{2}\left(\mathrm{CF}_{2}\right)_{9} \mathrm{CF}_{3}\right)\right]$, cytotoxicity was not observed at concentrations $<500 \mu \mathrm{M}$ under normal conditions whereas with the inclusion of a 2 hour heating period at $42{ }^{\circ} \mathrm{C}$ during the 72 hour incubation resulted in $\mathrm{IC}_{50}$ values as low as $5 \mu \mathrm{M}$ (in MCF-7 human breast cancer cells), i.e. two orders of magnitude greater inhibition of cell growth for the combination with hyperthermia. Notably, in non-cancerous human endothelial HEK-293 cells hyperthermia did not lead to such a large increase in cell growth inhibition with an observed $\mathrm{IC}_{50}$ value of $132 \mu \mathrm{M}$.

$\left[\mathrm{Ru}\left(\eta^{6}\right.\right.$-p-cymene $\left.) \mathrm{Cl}_{2}\left(\mathrm{C}_{5} \mathrm{H}_{4} \mathrm{~N}-3-\left(\mathrm{CH}_{2}\right)_{2}-\mathrm{CO}_{2}-\left(\mathrm{CH}_{2}\right)_{2}\left(\mathrm{CF}_{2}\right)_{9} \mathrm{CF}_{3}\right)\right]$ was evaluated in vivo in the same model used to test the chlorambucil derivative at an equivalent dose and administration/heating regime. ${ }^{102}$ Tumor growth inhibition of $66 \%$ was observed under normal conditions, which increases to $90 \%$ when combined with hyperthermia. Based on histochemical analysis tumor growth inhibition was attributed to the inhibition of cell proliferation and, in part, to necrosis, the latter feature having been observed in other combination studies employing hyperthermia. ${ }^{104}$ The toxicity of the compound appears to be largely limited to the heated tumor region as weight loss and other side effects were not observed. Moreover, the ruthenium distribution in the vital organs is not aggravated by the heat treatment process and the distribution of ruthenium is similar to other ruthenium compounds that are not cytotoxic. ${ }^{102,105,106}$ It has also been suggested that the selective delivery of the compound to the heat tumor site could also be due to temperature-dependent interactions with certain serum proteins. ${ }^{107}$

\section{Concluding remarks}

Randomized clinical trials have demonstrated overall patient survival prolongation with hyperthermia-drug treatment regimens applied to a wide range of malignancies. However, in order to make a local hyperthermia a more powerful cancer treatment strategy all possible factors of the treatment must be optimized. This optimization process is not trivial due to the difficulties associated with maintaining the optimum intra-tumor temperature, ${ }^{108,109}$ hyperthermia-induced drug targeting $^{110}$ and selective drug activation by heat.
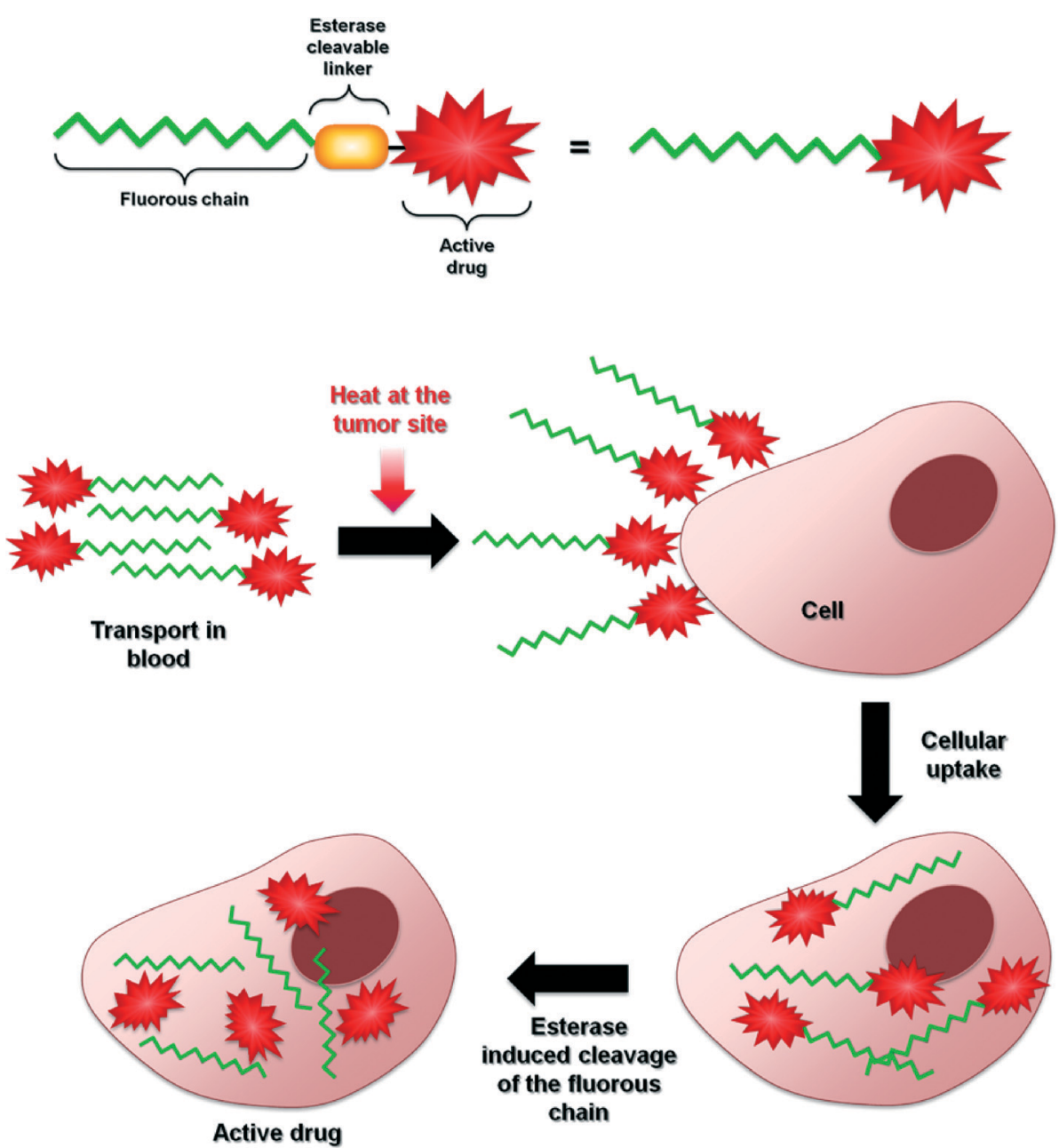

Fig. 9 Proposed generic mechanism of action of thermoresponsive fluorous-tagged drugs. 
Nevertheless, multiple studies have shown that hyperthermia complements chemosensitization and the mechanism of action of this dual-therapy appears to be dependent on the particular mechanism of each chemotherapeutic compound.

Further improvements of this treatment strategy will undoubtedly involve the development of more efficient heatresponsive drugs. The strategy reported herein, i.e. based on modifying clinically approved drugs or putative drug-like molecules with fluorous chains conjugated via ester linkages, certainly holds promise. A tentative, generic mechanism concerning drug delivery and heat activation is shown in Fig. 9 and, while the approach has thus far only been demonstrated on a limited number of compounds, it is not unreasonable to assume that it can be applied to almost any bioactive (anticancer) molecule. However, further validation of this approach is still needed as fluorous-tagged compounds also display relevant therapeutic properties under normal conditions ${ }^{111-113}$ and to determine whether it has advantages over the well-established use of thermoresponsive macromolecular drug delivery systems, some of which are progressing through clinical trials.

\section{Acknowledgements}

We thank the Swiss National Science Foundation and EPFL for financial support.

\section{References}

1 A. J. Breugom, M. Swets, J. F. Bosset, L. Collette, A. Sainato, L. Cionini, R. Glynne-Jones, N. Counsell, E. Bastiaannet, C. B. van den Broek, G. J. Liefers, H. Putter and C. J. van de Velde, Lancet Oncol., 2015, 16, 200-207.

2 E. Elimova, H. Shiozaki, R. Wadhwa, K. Sudo, Q. Chen, J. S. Estrella, M. A. Blum, B. Badgwell, P. Das, S. Song and J. A. Ajani, World J. Gastroenterol., 2014, 20, 13637-13647.

3 N. Pabla and Z. Dong, OncoTargets Ther., 2012, 3, 107-111.

4 W. Rao, Z. S. Deng and J. Liu, Crit. Rev. Biomed. Eng., 2010, 38, 101-116.

5 P. Wust, B. Hildebrandt, G. Sreenivasa, B. Rau, J. Gellermann, H. Riess, R. Felix and P. M. Schlag, Lancet Oncol., 2002, 3, 487-497.

6 O. Dahl, in Thermoradiotherapy and Thermochemotherapy, ed. M. H. Seegenschmiedt, P. Fessenden and C. C. Vernon, Springer Verlag, Berlin, 1995, vol. 1, pp. 103-121.

7 R. D. Issels, L. H. Lindner, J. Verweij, P. Wust, P. Reichardt, B. C. Schem, S. Abdel-Rahman, S. Daugaard, C. Salat, C. M. Wendtner, Z. Vujaskovic, R. Wessalowski, K. W. Jauch, H. R. Durr, F. Ploner, A. Baur-Melnyk, U. Mansmann, W. Hiddemann, J. Y. Blay and P. Hohenberger, Lancet Oncol., 2010, 11, 561-570.

8 M. H. Falk and R. D. Issels, Int. J. Hyperthermia, 2001, 17, 1-18.

9 E. Vorotnikova, R. Ivkov, A. Foreman, M. Tries and S. J. Braunhut, Int. J. Radiat. Biol., 2006, 82, 549-559.

10 R. Cavaliere, E. C. Ciocatto, B. C. Giovanella, C. Heidelberger, R. O. Johnson, M. Margottini, B. Mondovi, G. Moricca and A. Rossi-Fanelli, Cancer, 1967, 20, 1351-1381.
11 B. C. Giovanella, A. C. Morgan, J. S. Stehlin and L. J. Williams, Cancer Res., 1973, 33, 2568-2578.

12 B. Hildebrandt, P. Wust, O. Ahlers, A. Dieing, G. Sreenivasa, T. Kerner, R. Felix and H. Riess, Crit. Rev. Oncol. Hematol., 2002, 43, 33-56.

13 R. A. Coss and W. A. Linnemans, Int. J. Hyperthermia, 1996, 12, 173-196.

14 A. W. Konings and A. C. Ruifrok, Radiat. Res., 1985, 102, 86-98.

15 P. M. Gullino and F. H. Grantham, J. Natl. Cancer Inst., 1961, 27, 1465-1491.

16 G. C. Li, Cancer Res., 1984, 44, 4886s-4893s.

17 K. A. Ward and R. K. Jain, Int. J. Hyperthermia, 1988, 4, 223-250.

18 C. W. Song, H. Park and R. J. Griffin, in Thermotherapy for Neoplasia, Inflammation, and Pain, ed. M. Kosaka, T. Sugahara, K. Schmidt and E. Simon, Springer, Japan, 2001, ch. 44, pp. 394-407, DOI: 10.1007/978-4-431-67035-3_44.

19 A. Bettaieb, P. K. Wrzal and D. A. Averill-Bates, in Cancer Treatment - Conventional and Innovative Approaches, ed. L. Rangel, 2013, DOI: 10.5772/55795.

20 W. C. Dewey, L. E. Hopwood, S. A. Sapareto and L. E. Gerweck, Radiology, 1977, 123, 463-474.

21 J. E. Sisken, L. Morasca and S. Kibby, Exp. Cell Res., 1965, 39, 103-116.

22 A. Westra and W. C. Dewey, Int. J. Radiat. Biol. Relat. Stud. Phys., Chem. Med., 1971, 19, 467-477.

23 C. Streffer, Recent Results Cancer Res., 1988, 107, 7-16.

24 D. K. Kelleher, T. Engel and P. W. Vaupel, Int. J. Hyperthermia, 1995, 11, 241-255.

25 X. Sun, L. Xing, C. C. Ling and G. C. Li, Int. J. Hyperthermia, 2010, 26, 224-231.

26 R. J. Griffin, R. P. Dings, A. Jamshidi-Parsian and C. W. Song, Int. J. Hyperthermia, 2010, 26, 256-263.

27 C. T. Lee, T. Mace and E. A. Repasky, Int. J. Hyperthermia, 2010, 26, 232-246.

28 E. A. Repasky, S. S. Evans and M. W. Dewhirst, Cancer Immunol. Res., 2013, 1, 210-216.

29 J. Fucikova, P. Kralikova, A. Fialova, T. Brtnicky, L. Rob, J. Bartunkova and R. Spisek, Cancer Res., 2011, 71, 4821-4833.

30 E. G. Mimnaugh, R. W. Waring, B. I. Sikic, R. L. Magin, R. Drew, C. L. Litterst, T. E. Gram and A. M. Guarino, Cancer Res., 1978, 38, 1420-1425.

31 J. A. Dickson and M. Suzangar, Cancer Res., 1974, 34, 1263-1274.

32 K. Suzuki, Nagoya J. Med. Sci., 1967, 30, 1-21.

33 E. Ben-Hur and M. M. Elkind, Radiat. Res., 1974, 59, 484-495.

34 D. J. Honess and N. M. Bleehen, Br. J. Radiol., 1985, 58, 63-72.

35 D. J. Honess, J. Donaldson, P. Workman and N. M. Bleehen, Br. J. Cancer, 1985, 51, 77-84.

36 E. B. Douple and R. C. Richmond, Int. J. Radiat. Oncol., Biol., Phys., 1982, 8, 501-503.

37 O. Mella, R. Eriksen, O. Dahl and O. D. Laerum, Eur. J. Cancer Clin. Oncol., 1987, 23, 365-373. 
38 C. E. Ng, A. M. Bussey and G. P. Raaphorst, Int. J. Hyperthermia, 1996, 12, 551-567.

39 O. Dahl and O. Mella, Anticancer Res., 1982, 2, 359-364.

40 J. Overgaard, Int. J. Radiat. Oncol., Biol., Phys., 1989, 16, 535-549.

41 P. L. Ausmus, A. V. Wilke and D. L. Frazier, Cancer Res., 1992, 52, 4965-4968.

42 A. E.-M. Osman, M. M. Ahmed, M. T. Khayyal and M. M. elMerzabani, Tumori, 1993, 79, 268-272.

43 C. W. Helm, L. Randall-Whitis, R. S. Martin 3rd, D. S. Metzinger, M. E. Gordinier, L. P. Parker and R. P. Edwards, Gynecol. Oncol., 2007, 105, 90-96.

44 B. W. Loggie, R. A. Fleming, R. P. McQuellon, G. B. Russell, K. R. Geisinger and E. A. Levine, Am. Surg., 2001, 67, 999-1003.

45 S. Fujimoto, M. Takahashi, T. Mutou, K. Kobayashi, T. Toyosawa, E. Isawa, M. Sumida and H. Ohkubo, Cancer, 1997, 79, 884-891.

46 V. J. Verwaal, S. Bruin, H. Boot, G. van Slooten and H. van Tinteren, Ann. Surg. Oncol., 2008, 15, 2426-2432.

47 V. J. Verwaal, S. van Ruth, E. de Bree, G. W. van Sloothen, H. van Tinteren, H. Boot and F. A. Zoetmulder, J. Clin. Oncol., 2003, 21, 3737-3743.

48 O. Glehen, G. Passot, L. Villeneuve, D. Vaudoyer, S. BinDorel, G. Boschetti, E. Piaton and A. Garofalo, BMC Cancer, 2014, 14, 183.

49 K. E. Tschoep, S. Boeck, F. Berger, V. Maier, S. AbdelRahman, M. Kuhlencordt, C. Salat, M. Schmidt, V. Heinemann and R. D. Issels, J. Clin. Oncol., 2008, 26, 4635.

50 R. C. Rietbroek, M. S. Schilthuis, P. J. Bakker, J. D. van Dijk, A. J. Postma, D. Gonzalez Gonzalez, A. J. Bakker, J. van der Velden, T. J. Helmerhorst and C. H. Veenhof, Cancer, 1997, 79, 935-943.

51 R. de Wit, J. van der Zee, M. E. van der Burg, W. H. Kruit, A. Logmans, G. C. van Rhoon and J. Verweij, Br. J. Cancer, 1999, 80, 1387-1391.

52 C. M. Wendtner, S. Abdel-Rahman, J. Baumert, M. H. Falk, M. Krych, M. Santl, W. Hiddemann and R. D. Issels, Eur. J. Cancer, 2001, 37, 1609-1616.

53 R. D. Issels, S. W. Prenninger, A. Nagele, E. Boehm, H. Sauer, K. W. Jauch, H. Denecke, H. Berger, K. Peter and W. Wilmanns, J. Clin. Oncol., 1990, 8, 1818-1829.

54 M. Fiegl, M. Schlemmer, C. M. Wendtner, S. AbdelRahman, W. Fahn and R. D. Issels, Int. J. Hyperthermia, 2004, 20, 661-670.

55 H. Maeda, J. Controlled Release, 2012, 164, 138-144.

56 G. Kong, G. Anyarambhatla, W. P. Petros, R. D. Braun, O. M. Colvin, D. Needham and M. W. Dewhirst, Cancer Res., 2000, 60, 6950-6957.

57 K.-J. Chen, H.-F. Liang, H.-L. Chen, Y. Wang, P.-Y. Cheng, H.-L. Liu, Y. Xia and H.-W. Sung, ACS Nano, 2012, 7, 438-446.

58 J. K. Mills and D. Needham, Methods Enzymol., 2004, 387, 82-113.

59 M. L. Hauck, S. M. LaRue, W. P. Petros, J. M. Poulson, D. Yu, I. Spasojevic, A. F. Pruitt, A. Klein, B. Case, D. E. Thrall,
D. Needham and M. W. Dewhirst, Clin. Cancer Res., 2006, 12, 4004-4010.

60 C. D. Landon, J. Y. Park, D. Needham and M. W. Dewhirst, Open Nanomed. J., 2011, 3, 38-64.

61 G. N. C. Chiu, S. A. Abraham, L. M. Ickenstein, R. Ng, G. Karlsson, K. Edwards, E. K. Wasan and M. B. Bally, J. Controlled Release, 2005, 104, 271-288.

62 B. Banno, L. M. Ickenstein, G. N. C. Chiu, M. B. Bally, J. Thewalt, E. Brief and E. K. Wasan, J. Pharm. Sci., 2010, 99, 2295-2308.

63 J. Woo, G. N. C. Chiu, G. Karlsson, E. Wasan, L. Ickenstein, K. Edwards and M. B. Bally, Int. J. Pharm., 2008, 349, 38-46.

64 S. Purushotham, P. E. Chang, H. Rumpel, I. H. Kee, R. T. Ng, P. K. Chow, C. K. Tan and R. V. Ramanujan, Nanotechnology, 2009, 20, 305101.

65 T. Betancourt, B. Brown and L. Brannon-Peppas, Nanomedicine, 2007, 2, 219-232.

66 S. Louguet, B. Rousseau, R. Epherre, N. Guidolin, G. Goglio, S. Mornet, E. Duguet, S. Lecommandoux and C. Schatz, Polym. Chem., 2012, 3, 1408-1417.

67 N. Andhariya, B. Chudasama, R. V. Mehta and R. V. Upadhyay, J. Nanopart. Res., 2011, 13, 1677-1688.

68 A. Akbarzadeh, H. Mikaeili, N. Zarghami, R. Mohammad, A. Barkhordari and S. Davaran, Int. J. Nanomed., 2012, 7, 511-526.

69 K. Hynynen, Methods Mol. Biol., 2009, 480, 175-185.

70 M. I. Koukourakis, S. Koukouraki, I. Fezoulidis, N. Kelekis, G. Kyrias, S. Archimandritis and N. Karkavitsas, Br. J. Cancer, 2000, 83, 1281-1286.

71 G. P. Baronzio, G. Parmar, M. De Santis and A. Gramaglia, in Cancer Treatment - Conventional and Innovative Approaches, ed. L. Rangel, InTech, 2013, ch. 13.

72 K. Nakagawa, Y. Aoki, T. Fujimaki, M. Tago, A. Terahara, K. Karasawa, K. Sakata, Y. Sasaki, M. Matsutani and A. Akanuma, Int. J. Radiat. Oncol., Biol., Phys., 1998, 40, 1141-1149.

73 P. J. Miller, R. S. Hassanein, P. G. Giri, B. F. Kimler, P. O'Boynick and R. G. Evans, Int. J. Radiat. Oncol., Biol., Phys., 1990, 19, 275-280.

74 J. R. McDaniel, S. R. MacEwan, X. Li, D. C. Radford, C. D. Landon, M. Dewhirst and A. Chilkoti, Nano Lett., 2014, 14, 2890-2895.

75 J. R. McDaniel, J. Bhattacharyya, K. B. Vargo, W. Hassouneh, D. A. Hammer and A. Chilkoti, Angew. Chem., Int. Ed., 2013, 52, 1683-1687.

76 D. E. Meyer, B. C. Shin, G. A. Kong, M. W. Dewhirst and A. Chilkoti, J. Controlled Release, 2001, 74, 213-224.

77 M. Wende and J. A. Gladysz, J. Am. Chem. Soc., 2003, 125, 5861-5872.

78 C. Rocaboy and J. A. Gladysz, New J. Chem., 2003, 27, 39-49.

79 C. Gimbert, A. Vallribera, J. A. Gladysz and M. Jurisch, Tetrahedron Lett., 2010, 51, 4662-4665.

80 W. K. Hagmann, J. Med. Chem., 2008, 51, 4359-4369.

81 R. Filler and R. Saha, Future Med. Chem., 2009, 1, 777-791.

82 S. Purser, P. R. Moore, S. Swallow and V. Gouverneur, Chem. Soc. Rev., 2008, 37, 320-330. 
83 C. Heidelberger, N. K. Chaudhuri, P. Danneberg, D. Mooren, L. Griesbach, R. Duschinsky, R. J. Schnitzer, E. Pleven and J. Scheiner, Nature, 1957, 179, 663-666.

84 J. Wang, M. Sanchez-Rosello, J. L. Acena, C. del Pozo, A. E. Sorochinsky, S. Fustero, V. A. Soloshonok and H. Liu, Chem. Rev., 2014, 114, 2432-2506.

85 J. Osorio, Nat. Rev. Cardiol., 2010, 7, 541.

86 C. Hansch, A. Leo and D. Hoekman, Exploring QSAR: Volume 2: Hydrophobic, Electronic, and Steric Constants, American Chemical Society, 1995.

87 I. T. Horvath, G. Kiss, R. A. Cook, J. E. Bond, P. A. Stevens, J. Rabai and E. J. Mozeleski, J. Am. Chem. Soc., 1998, 120, 3133-3143.

88 B. Richter, A. L. Spek, G. van Koten and B. J. Deelman, J. Am. Chem. Soc., 2000, 122, 3945-3951.

89 F. O. Seidel and J. A. Gladysz, Adv. Synth. Catal., 2008, 350, 2443-2449.

90 M. Wende, R. Meier and J. A. Gladysz, J. Am. Chem. Soc., 2001, 123, 11490-11491.

91 M. P. Krafft, Adv. Drug Delivery Rev., 2001, 47, 209-228.

92 S. D. Xiong, L. Li, J. Jiang, L. P. Tong, S. L. Wu, Z. S. Xu and P. K. Chu, Biomaterials, 2010, 31, 2673-2685.

93 A. K. Renfrew, R. Scopelliti and P. J. Dyson, Inorg. Chem., 2010, 49, 2239-2246.

94 C. Scolaro, A. Bergamo, L. Brescacin, R. Delfino, M. Cocchietto, G. Laurenczy, T. J. Geldbach, G. Sava and P. J. Dyson, J. Med. Chem., 2005, 48, 4161-4171.

95 A. Bergamo, A. Masi, P. J. Dyson and G. Sava, Int. J. Oncol., 2008, 33, 1281-1289.

96 P. Nowak-Sliwinska, J. R. van Beijnum, A. Casini, A. A. Nazarov, G. Wagnieres, H. van den Bergh, P. J. Dyson and A. W. Griffioen, J. Med. Chem., 2011, 54, 3895-3902.

97 A. Weiss, B. H. Berndsen, M. Dubois, M. Müller, R. Schibli, A. W. Griffioen, P. J. Dyson and P. Nowak-Sliwinska, Chem. Sci., 2014, 5, 4742-4748.

98 R. E. Aird, J. Cummings, A. A. Ritchie, M. Muir, R. E. Morris, H. Chen, P. J. Sadler and D. I. Jodrell, Br. J. Cancer, 2002, 86, 1652-1657.
99 S. M. Guichard, R. Else, E. Reid, B. Zeitlin, R. Aird, M. Muir, M. Dodds, H. Fiebig, P. J. Sadler and D. I. Jodrell, Biochem. Pharmacol., 2006, 71, 408-415.

100 A. Bergamo, A. Masi, A. F. Peacock, A. Habtemariam, P. J. Sadler and G. Sava, J. Inorg. Biochem., 2010, 104, 79-86.

101 C. M. Clavel, O. Zava, F. Schmitt, B. H. Kenzaoui, A. A. Nazarov, L. Juillerat-Jeanneret and P. J. Dyson, Angew. Chem., Int. Ed., 2011, 50, 7124-7127.

102 C. M. Clavel, P. Nowak-Sliwinska, E. Paunescu, A. W. Griffioen and P. J. Dyson, Chem. Sci., 2015, 6, 2795-2801.

103 C. M. Clavel, E. Paunescu, P. Nowak-Sliwinska and P. J. Dyson, Chem. Sci., 2014, 5, 1097-1101.

104 W. Nie, X. L. Ma, Y. X. Sang, Y. L. Li, X. Gao, G. C. Xu, G. B. Shen, H. S. Shi, X. X. Liu, F. T. Wang and Y. Q. Wei, Clin. Exp. Med., 2014, 14, 203-213.

105 S. Zorzet, A. Sorc, C. Casarsa, M. Cocchietto and G. Sava, Met.-Based Drugs, 2001, 8, 1-7.

106 M. Cocchietto and G. Sava, Pharmacol. Toxicol., 2000, 87, 193-197.

107 P. Nowak-Sliwinska, C. M. Clavel, E. Paunescu, M. T. Te Winkel, A. W. Griffioen and P. J. Dyson, Mol. Pharmaceutics, 2015, 12, 3089-3096.

108 C. D. Kaddi, J. H. Phan and M. D. Wang, Nanomedicine, 2013, 8, 1323-1333.

109 G. M. Hahn, Br. J. Cancer, Suppl., 1982, 5, 238-242.

110 B. M. Dicheva and G. A. Koning, Expert Opin. Drug Delivery, 2014, 11, 83-100.

111 E. Paunescu, C. M. Clavel, P. Nowak-Sliwinska, A. W. Griffioen and P. J. Dyson, ACS Med. Chem. Lett., 2015, 6, 313-317.

112 C. M. Clavel, E. Paunescu, P. Nowak-Sliwinska, A. W. Griffioen, R. Scopelliti and P. J. Dyson, J. Med. Chem., 2014, 57, 3546-3558.

113 E. Paunescu, P. Nowak-Sliwinska, C. M. Clavel, R. Scopelliti, A. W. Griffioen and P. J. Dyson, ChemMedChem, 2015, 10, 1539-1547. 